\title{
Growth Failure in Children with Sickle Cell Anaemia
}

\author{
Ikegwuonu Charles ${ }^{1}$, Manyike Chuka ${ }^{2}$, Ezeanosike Obumneme ${ }^{1}$, Ujunwa Fortune ${ }^{1}$, Onoh Emmanuel ${ }^{1}$, Ikegwuonu Cordis ${ }^{3}$ \\ 1. Department of Paediatrics, Alex Ekwueme Federal University Teaching Hospital, Abakaliki, Ebonyi State, Nigeria. \\ 2. Department of Paediatrics, Ebonyi State University Teaching Hospital, Abakaliki, Ebonyi State, Nigeria. \\ 3. Department of Public Health, Alex Ekwueme Federal University Teaching Hospital, Abakaliki, Ebonyi State, Nigeria.
}

\section{Abstract:-}

\section{$>$ Background}

Sickle cell disease is a group of inherited sickling disorders consequent upon abnormalities of haemoglobin synthesis. It is one of the common causes of retardation in both physical growth and sexual maturation in children, as a result of chronic anaemia and consequent hypoxia that occur in several organs.

\section{Objectives}

To determine the anthropometric indices (weight, height and Body Mass Index) of children with sickle cell anaemia (SCA) and compare them with that of children with normal haemoglobin; haemoglobin AA (HbAA)

\section{$>$ Method}

A cross-sectional study carried out in a tertiary hospital in South East Nigeria, involving 164 children with SCA aged 2 - 17 years who were in steady state. The participants in the control group were age- and sexmatched HbAA children with the study participants. Weight was measured using a calibrated digital weighing scale (Universal Digital Weight Indicator 7400 series, Pennsylvania, USA) to the nearest $100 \mathrm{gm}$, height was measured using a calibrated stadiometer (SECA®stadiometer, model 217, SECA Corp., Hamburg, Germany) with measuring range of $20-205$ $\mathrm{cm}, \mathrm{BMI}$ was calculated using the formula:

$$
\frac{\text { Weight }(\boldsymbol{k g})}{\operatorname{Height}^{2}(\mathrm{~m})}
$$

They were analysed using the Statistical Package for Social Science (SPSS) version 23.

\section{$>$ Result}

A total of $164 \mathrm{SCA}$ children with equal numbers of age- and sex-matched HbAA controls, were studied. The mean weight of children with SCA was $29.42 \mathrm{~kg}$ (SD, 8.6), which was significantly lower than that of $\mathrm{HbAA}$ children $(32.86 \mathrm{~kg}(\mathrm{SD}, 10.6))(\mathrm{p}<0.01)$. Also, the mean height of children with SCA of $1.31 \mathrm{~m}(\mathrm{SD}, 0.2)$ was lower than that of $\mathrm{HbAA}$ children, $1.36 \mathrm{~m}$ (SD, 0.2), though not significant $(p=0.05)$. However, the mean BMI of children with SCA was $15.85 \mathrm{~kg} / \mathrm{m}^{2}$ (SD, 2.6) and it was significantly lower than that of $\mathrm{HbAA}$ children $\left(16.46 \mathrm{~kg} / \mathrm{m}^{2}(\mathrm{SD}, 1.9)\right)(\mathrm{p}<0.01)$

\section{Conclusion}

The anthropometric indices of children with SCA were found to be reduced when compared to that of HbAA children, with the weight and BMI significantly affected.

Keywords:- SCA, Growth, Anthropometry, Ischaemia.

\section{INTRODUCTION}

Sickle cell disease is a group of inherited sickling disorders consequent upon abnormalities of haemoglobin synthesis. ${ }^{1}$ It comprises sickle cell anaemia (HbSS), sickle cell trait (HbAS), heterozygous states of haemoglobin $\mathrm{S}$ and haemoglobins C, D, E and some others with "S" gene in the heterozygous state. ${ }^{1}$ The most severe form of these disorders is sickle cell anaemia (SCA). ${ }^{1}$ Tropical Africa has the highest prevalence of SCA and Nigeria has the highest burden, ${ }^{2}$ with approximately $3 \%$ of the population having SCA and $25-40 \%$ of the population having the trait. ${ }^{1}$

The sickling of the red blood cells results in chronic haemolytic anaemia and also, occlusion of blood vessels, which affect several systems in the body. ${ }^{3,4}$ The habitus of children with SCA is as a result of the involvement of the musculoskeletal system. ${ }^{5}$ The changes in physique include; small for age due to growth retardation, increased anteroposterior diameter of chest, prognathism and arachnodactyly. ${ }^{5}$ These are due to the effect of the chronic anaemia, with resultant chronic hypoxaemia of the bone marrow, leading to bone marrow hyperplasia, extension of bone marrow into the bone cortex, with consequent widening of the diploe spaces and thinning of the cortex of the bones. ${ }^{5}$ Apart from the effects of chronic anaemia on the bone, other causes of poor growth include endocrine dysfunction and nutritional deficiencies. ${ }^{6,7,8}$ The chronic anaemia and consequent hypoxia of the pituitary gland leads to endocrine abnormality, especially reduced growth hormone production and hypogonadism, thus, the growth failure. ${ }^{6}$ Children with SCA usually have normal weight and height at birth. ${ }^{9,10}$ However, as they get older, there is a consequent retardation of growth velocity, which starts in the pre-pubertal period and gets worse during puberty. ${ }^{11}$ This growth failure is seen as retardation of one or more of the anthropometric indices such as weight, height and body mass index (BMI). ${ }^{12,13}$ The BMI has been found to be a good tool for the assessment of the nutritional status of a child, as well as an important index for the assessment of growth and development. ${ }^{14}$ Conversely, overweight and obesity, with its attendant complications such as 
hypertension, have also been observed in children with SCA in both developed and developing countries. ${ }^{15-18}$

Thus, the evaluation of the anthropometric indices such as weight, height and BMI of children with SCA will assist in the assessment and monitoring of their nutritional status, growth and development, such that growth failure or overweight malnutrition may be detected early and subsequent intervention instituted early.

\section{METHODOLOGY}

\section{Study Area:}

This study was carried out in the Alex Ekwueme Federal University Teaching Hospital Abakaliki (AEFUTHA), Ebonyi State. It serves a large proportion of the inhabitants of Ebonyi State and beyond. Its Paediatric Department has a sickle cell unit which sees all paediatric sickle cell anaemia patients. The patients are usually first seen at the children emergency room or the children outpatient clinic, when they first present and are diagnosed to have SCA or through referrals from private and government health facilities.

\section{Study Population:}

These were children aged 2 years to 17 years with SCA in steady state (Group A) who presented in the sickle cell clinic of AE-FUTHA and who fulfilled the criteria for inclusion into the study. The controls comprised of age- and sex-matched non-SCA children with genotype HbAA (Group B) who presented in children outpatient and wellchild clinic of AE-FUTHA.

\section{$>$ Inclusion and Exclusion Criteria:}

Children aged 2 years to 17 years with SCA in steady state. The steady state was defined as absence of crisis or blood transfusion in the preceding four weeks before recruitment. ${ }^{19,20}$ The controls comprised of children with normal genotype (HbAA). Participants with history of comorbidities like congenital heart disease, rheumatic heart disease or other chronic diseases were excluded from the study.

\section{Ethical Consideration and Consent:}

Ethical approval was obtained from the Research and Ethical committee of the AE-FUTHA before commencement of the study. An informed consent was obtained from the parents and assent obtained from their children who were 7 years of age and above.

\section{Study Design:}

This was a hospital-based cross-sectional study.

\section{Sampling Method:}

One hundred and sixty-four children with SCA were consecutively recruited from the SCA out-patient clinic until the minimum sample was achieved. To avoid double recruitment, patients' folders were coded. Each day after recruitment of participants from the sickle cell clinic, equal numbers of age- and sex-matched controls were recruited from the children outpatient and well-baby clinic. This study was carried out over a period of 3 months.

\section{Data Collection:}

Information such as age and gender were obtained. The heights and weights of the participants were measured using standard methods and the BMI was computed using the height and weight. Height was measured using a calibrated stadiometer (SECA®Stadiometer, model 217, SECA Corp., Hamburg, Germany). The participant had neither footwear nor cap. The heels, buttocks, shoulder and occiput were made to be on the same vertical plane, with their hands placed on their sides. Their eye-ear planes were perpendicular to the wall (Frankfurt plane). ${ }^{21}$ At this position, the horizontal head piece was lowered until it touched the top of the head and the height was read off. The height was measured to the nearest 0.1 centimetre. The weight was measured using a calibrated digital weighing scale (Universal 7400) to the nearest 100gm. The children were putting on light clothing and were asked to stand erect, barefoot and look forward. The BMI was then calculated for each participant using the formula ${ }^{22}$

$$
\frac{W e i g h t(k g)}{\operatorname{Height}^{2}(m)}
$$

Each BMI value was converted to BMI Z-score (standard deviation score) for age and gender using the WHO 2007 reference growth charts. ${ }^{23}$ The participants were then categorized as severe thinness if $<-3$ SD, thinness if < $-2 \mathrm{SD}$, normal if the participant fall between -2SD and +1SD, overweight if $>+1 \mathrm{SD}$ and Obesity if $>+2 \mathrm{SD} .^{23}$

\section{$>$ Data Analysis:}

The data collected were entered and analysed using the Statistical Package for Social Science (SPSS) version 23 for Microsoft windows 8 . The results were presented in tables. Descriptive statistics such as frequency and percentages were used to describe characteristics of the subjects such as gender and number of participants within each age group. Continuous variables such as weight and height were subjected to test of normality and were found to be normally distributed, using Shapiro-Wilks test for normality ( $p>$ $0.05) .{ }^{24}$ Hence, they were analysed using mean and standard deviation, and the results obtained were compared between groups using student's " $t$ " test. At confidence level of 95\%, any difference observed between the 2 groups was said to be significant if the $\mathrm{p}$-value was $<0.05$. 


\section{RESULTS}

\section{Gender and age distribution:}

A total of 328 children (192 males and 136 females), comprising 164 children with SCA (group A) and 164 age- and sexmatched HbAA controls (group B), were recruited for this study. The children were within the ages of 2- 17 years, with a mean age of 9.7 years (SD, 4.56) for both SCA and HbAA children and a male: female ratio of 1.4:1 in both groups. This is illustrated in Table I.

\begin{tabular}{|c|c|c|c|}
\hline Characteristics & Group A & Group B & Total \\
\hline Gender & $\mathrm{n}(\%)$ & $\mathrm{n}(\%)$ & $\mathrm{n}$ \\
\hline Male & $96(58.5)$ & $96(58.5)$ & 192 \\
\hline Female & $68(41.5)$ & $68(41.5)$ & 136 \\
\hline Total & $164(100)$ & $164(100)$ & 328 \\
\hline Age (years) & $\mathrm{n}(\%)$ & $\mathrm{n}(\%)$ & $\mathrm{n}$ \\
\hline $2-5$ & $38(23.2)$ & $38(23.2)$ & 76 \\
\hline $6-12$ & $74(45.1)$ & $74(45.1)$ & 148 \\
\hline $13-17$ & $52(31.7)$ & $52(31.7)$ & 104 \\
\hline TOTAL & $164(100)$ & $164(100)$ & 328 \\
\hline
\end{tabular}

Table I: Gender and age distribution of children with SCA and controls

\section{Anthropometric Indices:}

The overall mean weight, height and BMI of children with SCA were lower than that of HbAA children. However, the difference in height between the two groups was not significant. This is shown in Table II.

\begin{tabular}{|c|c|c|c|}
\hline & Group A (SCA) & Group B (HbAA) & p- value \\
\hline Mean weight, $\mathrm{kg}$ (SD) & $29.42(8.6)$ & $32.86(10.6)$ & $<0.01$ \\
\hline Mean height, m (SD) & $1.31(0.2)$ & $1.36(0.2)$ & 0.05 \\
\hline Mean BMI, kg/m ${ }^{2}$ (SD) & $15.85(2.6)$ & $16.46(1.9)$ & $<0.01$ \\
\hline
\end{tabular}

Table II. Mean anthropometric measurements of sickle cell and HbAA children

Considering the gender of the participants, the mean weight, height and BMI of the female children with SCA were significantly higher than their male counterparts. This is in contrast to what was observed in HbAA children, where all the 3 anthropometric indices were higher among the male participants than the female participants. This is illustrated in Table III.

\begin{tabular}{|c|c|c|c|}
\hline & Male & Female & p- value \\
\hline SCA children & & & $<0.01$ \\
\hline Mean weight, $\mathrm{kg}(\mathrm{SD})$ & $26.13(11.9)$ & $31.81(12.8)$ & $<0.01$ \\
\hline Mean height, m (SD) & $1.27(2.8)$ & $1.37(2.2)$ & $<0.01$ \\
\hline Mean BMI, kg/m ${ }^{2}$ (SD) & $15.20(2.3)$ & $16.06(2.9)$ & 0.04 \\
\hline HbAA children & & & $27.44(12.4)$ \\
\hline Mean weight, $\mathrm{kg}$ (SD) & $30.36(12.8)$ & $1.29(2.3)$ & 0.04 \\
\hline Mean height, m (SD) & $1.35(2.7)$ & $16.27(2.0)$ & 0.17 \\
\hline
\end{tabular}

Table III. Mean anthropometric measurements of male and female participants

The weight and height of SCA children and HbAA children among the different ages are shown in Tables IV and V. In the male participants, though the weights of SCA children were lower than that of HbAA children across most age groups, there was no significant difference in weight between both groups of children within the ages of 2 - 6 years and also, those within the ages of 15 - 17 years. However, the weight of SCA children within the ages of $7-14$ years was significantly lower than their counterparts among the HbAA children. Likewise, among the female participants, the age range with significant difference in weight between the 2 groups was 7 - 16 years. The heights of male SCA children were lower than the heights of their corresponding ages among the HbAA children, but the difference was only significant among children within the ages of 4 - 16 years. This was also observed among the female participants, but the significant difference in height was predominantly observed among those within the ages of $11-17$ years. 
ISSN No:-2456-2165

\begin{tabular}{|c|c|c|c|c|c|c|}
\hline $\begin{array}{c}\text { Age } \\
\text { (years) }\end{array}$ & $\begin{array}{c}\text { Group A } \\
\text { Weight(kg) } \\
\text { mean (SD) }\end{array}$ & $\begin{array}{c}\text { Group B } \\
\text { Weight(kg) } \\
\text { mean (SD) }\end{array}$ & p- value & $\begin{array}{c}\text { Group A } \\
\text { Height(m) } \\
\text { mean(SD) }\end{array}$ & $\begin{array}{c}\text { Group B } \\
\text { Height(m) } \\
\text { mean(SD) }\end{array}$ & p-value \\
\hline 2 & $12.40(1.1)$ & $11.90(1.2)$ & 0.37 & $0.92(0.04)$ & $0.94(0.17)$ & 0.74 \\
3 & $15.30(2.5)$ & $15.00(1.4)$ & 0.79 & $0.94(0.22)$ & $0.98(0.37)$ & 0.81 \\
4 & $16.60(1.4)$ & $16.20(1.2)$ & 0.46 & $0.96(0.07)$ & $1.04(0.05)$ & $<0.01$ \\
5 & $17.80(0.5)$ & $17.90(1.7)$ & 0.86 & $1.06(0.06)$ & $1.13(0.03)$ & $<0.01$ \\
6 & $18.50(0.3)$ & $19.50(1.6)$ & 0.19 & $1.10(0.02)$ & $1.16(0.04)$ & 0.01 \\
7 & $19.80(1.1)$ & $21.90(1.5)$ & $<0.01$ & $1.15(0.02)$ & $1.20(0.01)$ & $<0.01$ \\
8 & $21.90(1.2)$ & $23.85(1.4)$ & 0.01 & $1.21(0.01)$ & $1.25(0.03)$ & $<0.01$ \\
9 & $24.20(0.2)$ & $26.20(1.2)$ & $<0.01$ & $1.25(0.01)$ & $1.30(0.03)$ & $<0.01$ \\
10 & $27.40(1.3)$ & $33.30(1.2)$ & $<0.01$ & $1.31(0.02)$ & $1.37(0.02)$ & $<0.01$ \\
11 & $30.60(1.5)$ & $36.10(1.1)$ & $<0.01$ & $1.37(0.03)$ & $1.42(0.03)$ & $<0.01$ \\
12 & $32.00(1.8)$ & $39.10(2.2)$ & $<0.01$ & $1.42(0.02)$ & $1.48(0.02)$ & $<0.01$ \\
13 & $34.20(2.9)$ & $42.20(2.2)$ & $<0.01$ & $1.44(0.02)$ & $1.53(0.04)$ & $<0.01$ \\
14 & $37.00(3.4)$ & $47.40(4.7)$ & $<0.01$ & $1.52(0.03)$ & $1.58(0.04)$ & $<0.01$ \\
15 & $45.90(2.6)$ & $47.10(5.3)$ & 0.46 & $1.60(0.05)$ & $1.64(0.03)$ & 0.02 \\
16 & $47.40(2.3)$ & $48.20(4.0)$ & 0.63 & $1.63(0.02)$ & $1.68(0.02)$ & $<0.01$ \\
17 & $49.30(3.5)$ & $50.80(5.5)$ & 0.48 & $1.67(0.05)$ & $1.70(0.04)$ & 0.16 \\
\hline
\end{tabular}

Table IV: Mean weight and height of male participants

\begin{tabular}{|c|c|c|c|c|c|c|}
\hline $\begin{array}{c}\text { Age } \\
\text { (years) }\end{array}$ & $\begin{array}{c}\text { Group A } \\
\text { Weight(kg) } \\
\text { mean (SD) }\end{array}$ & $\begin{array}{c}\text { Group B } \\
\text { Weight(kg) } \\
\text { mean (SD) }\end{array}$ & p- value & $\begin{array}{c}\text { Group A } \\
\text { Height(m) } \\
\text { mean (SD) }\end{array}$ & $\begin{array}{c}\text { Group B } \\
\text { Height(m) } \\
\text { Mean (SD) }\end{array}$ & p-value \\
\hline 2 & $12.10(1.2)$ & $12.08(1.3)$ & 0.97 & $0.90(0.02)$ & $0.94(0.01)$ & $<0.01$ \\
3 & $15.00(1.5)$ & $15.30(1.4)$ & 0.71 & $0.91(0.01)$ & $0.96(0.12)$ & 0.31 \\
4 & $16.10(1.6)$ & $16.18(1.5)$ & 0.90 & $0.93(0.03)$ & $0.98(0.01)$ & $<0.01$ \\
5 & $17.25(0.3)$ & $17.60(1.2)$ & 0.39 & $1.04(0.01)$ & $1.10(0.04)$ & $<0.01$ \\
6 & $18.10(0.4)$ & $19.20(1.3)$ & 0.10 & $1.08(0.05)$ & $1.14(0.07)$ & 0.12 \\
7 & $19.50(1.2)$ & $21.15(1.0)$ & $<0.01$ & $1.13(0.03)$ & $1.19(0.01)$ & $<0.01$ \\
8 & $20.86(1.5)$ & $23.75(1.6)$ & $<0.01$ & $1.19(0.02)$ & $1.23(0.06)$ & 0.11 \\
9 & $23.10(0.8)$ & $25.42(1.6)$ & 0.04 & $1.24(0.04)$ & $1.28(0.08)$ & 0.23 \\
10 & $25.34(1.0)$ & $32.24(1.5)$ & $<0.01$ & $1.38(0.02)$ & $1.42(0.01)$ & 0.07 \\
11 & $28.06(1.2)$ & $35.35(1.3)$ & $<0.01$ & $1.39(0.04)$ & $1.45(0.06)$ & $<0.01$ \\
12 & $30.43(1.4)$ & $37.32(2.8)$ & $<0.01$ & $1.46(0.01)$ & $1.52(0.03)$ & $<0.01$ \\
13 & $32.18(1.8)$ & $40.15(1.8)$ & $<0.01$ & $1.49(0.04)$ & $1.54(0.06)$ & 0.03 \\
14 & $36.08(2.5)$ & $46.10(1.9)$ & $<0.01$ & $1.55(0.04)$ & $1.60(0.05)$ & 0.04 \\
15 & $43.30(2.0)$ & $48.50(6.2)$ & $<0.01$ & $1.57(0.05)$ & $1.64(0.03)$ & $<0.01$ \\
16 & $45.22(1.8)$ & $49.65(3.8)$ & 0.01 & $1.63(0.02)$ & $1.68(0.02)$ & $<0.01$ \\
17 & $50.50(2.7)$ & $52.20(5.2)$ & 0.38 & $1.65(0.05)$ & $1.70(0.04)$ & 0.02 \\
\hline
\end{tabular}


The mean BMI value and BMI z-score of SCA and HbAA children are shown in Tables VI and VII. The mean BMI among male SCA children within the ages of $7-17$ years was significantly lower than their counterparts among the HbAA children, while such significant difference was noted mostly in female participants within the ages of 10 - 17 years.

There was no significant difference in the number of participants with normal BMI between both groups. However, moderate thinness was significantly higher in SCA children $(\mathrm{p}<0.01)$, while overweight was significantly higher in HbAA children $(\mathrm{p}<0.01)$.

\begin{tabular}{|c|c|c|c|c|c|c|}
\hline $\begin{array}{l}\text { Age } \\
\text { (years) }\end{array}$ & $\begin{array}{l}\text { Group A (Male) } \\
\text { Mean BMI kg/m } \\
\text { (SD) }\end{array}$ & $\begin{array}{l}\text { Group B (Male) } \\
\text { Mean BMI kg/m² } \\
\text { (SD) }\end{array}$ & p- value & 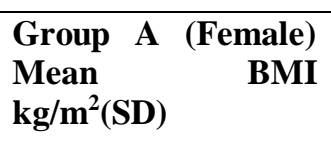 & $\begin{array}{l}\text { Group B } \\
\text { Mean BMI } \\
\text { (SD) }\end{array}$ & $\begin{array}{l}\text { p- } \\
\text { value }\end{array}$ \\
\hline $\begin{array}{l}2 \\
3 \\
4 \\
5 \\
6 \\
7 \\
8 \\
9 \\
10 \\
11 \\
12 \\
13 \\
14 \\
15 \\
16 \\
17\end{array}$ & $\begin{array}{l}16.40(1.2) \\
16.60(1.5) \\
16.20(1.4) \\
14.20(1.2) \\
14.60(1.4) \\
14.50(1.5) \\
15.15(1.3) \\
15.20(1.8) \\
15.80(1.2) \\
15.60(1.7) \\
14.70(1.4) \\
14.50(1.4) \\
14.88(2.0) \\
15.70(1.6) \\
15.90(1.5) \\
16.20(1.7)\end{array}$ & $\begin{array}{l}15.60(1.3) \\
15.80(1.4) \\
16.04(1.2) \\
15.30(1.4) \\
15.70(1.3) \\
15.50(1.0) \\
16.55(1.3) \\
16.95(1.2) \\
18.40(1.6) \\
18.35(1.3) \\
17.42(2.0) \\
17.25(1.3) \\
17.80(1.6) \\
19.80(1.8) \\
20.65(1.8) \\
20.08(2.1)\end{array}$ & $\begin{array}{l}0.19 \\
0.32 \\
0.77 \\
0.08 \\
0.19 \\
0.03 \\
0.04 \\
0.04 \\
<0.01 \\
<0.01 \\
<0.01 \\
<0.01 \\
<0.01 \\
<0.01 \\
<0.01 \\
<0.01\end{array}$ & $\begin{array}{l}16.20(1.3) \\
16.38(1.1) \\
16.15(1.3) \\
14.00(1.3) \\
14.28(1.5) \\
14.13(1.3) \\
15.24(1.2) \\
15.04(1.4) \\
15.30(1.2) \\
15.40(1.4) \\
14.44(1.1) \\
14.40(1.7) \\
14.75(1.8) \\
15.52(1.5) \\
15.53(2.2) \\
16.65(1.5)\end{array}$ & $\begin{array}{l}15.38(1.6) \\
15.70(1.2) \\
16.10(1.4) \\
15.20(1.6) \\
15.40(1.7) \\
15.39(1.2) \\
16.64(1.4) \\
16.12(1.8) \\
18.22(1.1) \\
18.05(1.6) \\
17.10(1.3) \\
17.14(1.6) \\
17.60(1.7) \\
19.42(1.3) \\
20.48(1.2) \\
20.07(1.4)\end{array}$ & $\begin{array}{l}0.25 \\
0.29 \\
0.07 \\
0.08 \\
0.25 \\
<0.01 \\
0.05 \\
0.20 \\
<0.01 \\
<0.01 \\
<0.01 \\
<0.01 \\
<0.01 \\
<0.01 \\
<0.01 \\
<0.01\end{array}$ \\
\hline
\end{tabular}

Table VI: Mean BMI of study participants

\begin{tabular}{|c|c|c|c|}
\hline & $\begin{array}{c}\text { Group A } \\
\mathrm{n}(\%)\end{array}$ & $\begin{array}{c}\text { Group B } \\
\mathrm{n}(\%)\end{array}$ \\
\hline BMI z-score & & & p- value \\
Severe thinness & - & - & - \\
Moderate thinness & $40(24.4)$ & $9(5.5)$ & $<0.01$ \\
Normal & $117(71.3)$ & $24(75.6)$ & 0.38 \\
Overweight & $7(4.3)$ & $4(2.4)$ & - \\
Obesity & $0(0)$ & $164(100)$ & 0.01 \\
TOTAL & $164(100)$ & \\
\hline
\end{tabular}

Table VII: The BMI z-score of study participants

\section{DISCUSSION}

The overall mean of all the anthropometric indices (weight, height and BMI) evaluated in this study were lower in children with SCA when compared to that of HbAA children and these were statistically significant except for the difference in mean height. This portrays the negative effect of sickle cell anaemia on the growth. Sickle cell anaemia has been previously reported to retard the physical growth of children, ${ }^{25}$ attributable to several factors such as chronic anaemia- induced reduction in growth hormone production, ${ }^{8}$ increased energy requirement for increased erythropoiesis as a consequence of chronic haemolysis, ${ }^{26}$ and chronic hypoxemia of bone marrow. ${ }^{5}$ Similar findings have been observed in several studies within ${ }^{8,25,27}$ and outside Nigeria. ${ }^{7,9,28,29}$ Among children with SCA, males had significantly lower overall mean weight, height and BMI than the females. This was in contrast to what was observed in the control participants, where the anthropometric indices were higher in males than females. This may suggest that the growth retardation caused by sickle cell anaemia is more pronounced in males than in females and may be explained by the observation that puberty has a positive effect on growth in females with SCA, as the hormonal changes that occur in girls during puberty leads to growth recovery, whereas, such puberty induced growth recovery was not observed to occur in boys. ${ }^{11}$ Also, it has been noted that boys with SCA have impaired hypothalamic-pituitarygonadal axis regulatory feedback mechanism, leading to poor testosterone response to gonadotrophin-releasing hormone, ${ }^{30}$ with consequent severe hypogonadism in males, while females have less comparable endocrine deficiency. This therefore leads to retarded physical and sexual maturation in males. ${ }^{7,30}$ Other studies have also observed 
more growth failure in male children with SCA than in female children with SCA. ${ }^{30,31}$ This is in contrast to the observation by Kazadi et al, ${ }^{28}$ where it was observed that there was no difference in anthropometric indices between both genders. The reason for their finding might be explained by the fact that $64 \%$ of their study participants were below 9 years of age, thus, truncating the effect of puberty on physical growth as earlier stated. The chronicity of the effect of SCA on the physical growth is portrayed by the observation of a more significant reduction in growth among older children with SCA when compared to their HbAA counterparts. The significant reduction in weight and BMI of children with SCA occurred at an almost similar age range among male and female participants, unlike that of height, where the significant reduction in height occurred at an earlier age among males with SCA when compared to the females. This finding of physical growth retardation being more in older children shows that it may take some time before a child with SCA manifest with overt features of growth failure, especially if not detected early. This is similar to the finding by Odetunde et $a l^{8}$ where they observed that though the weight of children with SCA were lower than that of HbAA children across all ages, it was more significant among the adolescents. Onukwuli et $a l^{25}$ however, observed that the lower weight and BMI of children with SCA when compared to non-SCA children was significant in both younger and older children except in those aged 14-15 years (for weight) and 10-11 years (for BMI). In our study, though no participant had severe thinness, moderate thinness was significantly seen in children with SCA than in HbAA children. This is in agreement with the weight and height retardation earlier described in them. In contrast to the growth failure which has been previously shown to occur in children with SCA, ${ }^{7,11,28,30,31} 4.3 \%$ of children in our study were overweight. The reason for this observation is not clear, but some factors which were not evaluated for in this study may have contributed to this. They include the socio-economic status of the caregivers and hence, the child's nutrition; and the severity of the sickle cell anaemia, because those with milder forms of SCA may have a lesser negative impact on their physical growth. The finding of children with SCA who were overweight was similar to the findings by Hall et $a l^{31}$ and Esezobar et $a l .^{32}$ Both studies observed that a small percentage of the children with SCA were found to be overweight, while a smaller percentage had obesity. This finding in our study may suggest that under-nutrition (seen as reduced anthropometric indices) may not be the only growth abnormality that should be of concern in children with SCA, rather, over-nutrition should also be sought for. This is important because, overweight and obese SCA children are predisposed to metabolic syndrome such as hypertension and its complications, and this has been observed in children with SCA in both developed and developing countries. ${ }^{15-18}$

\section{CONCLUSION}

The weight, height and BMI of children with SCA were lower than their age- and gender-matched HbAA children. This portrays the negative impact of SCA on the physical growth of children with sickle cell anaemia. On the other hand, a small proportion of children with SCA were also found to be overweight.

\section{REFERENCES}

[1]. Adekile AD, Adeodu OO, Adegoke SA. Haemoglobinopathies. In Azubuike JC, Nkangineme KEO (editors). Paediatrics and Child Health in a Tropical Region, 3rd ed. Lagos: Educational printing and publishing; 2016. p.1051-1062

[2]. Anie KA, Egunjobi FE, Akinyanju OO. Psychosocial impact of sickle cell disorder: perspectives from a Nigerian setting. Global. Health. 2010;6:1-6.

[3]. Weatherall DJ, Clegg JB. Inherited haemoglobin disorders: an increasing global health problem. Bull. World Health Organ. 2001;79:704-712

[4]. Morris CR. Mechanisms of vasculopathy in sickle cell disease and thalassemia. Hematology Am Soc Hematol Educ Program. 2008;2008:177-185

[5]. Weatheral DJ. Genetic disorders of hemoglobin. In Hoffbrand AV, Lewis SM, Tuddenham EG, editors. Postgraduate Hematology, $14^{\text {th }}$ ed: Oxford. Butterworth Heinemann; 1999. p.111-118

[6]. Cepeda ML, Allen FH, Cepeda NJ, Yang YM. Physical growth, sexual maturation, body image and sickle cell disease. J Natl Med Assoc. 2000;92:10-14

[7]. Barden EM, Kawchak DA, Ohene-Frepong K, Stallings VA, Zemel BS. Body composition in children with sickle cell disease. Am J Clin Nutr. 2002;76:218 225.

[8]. Odentunde OI, Chinawa JM, Achigbu KI, Achigbu EO. Body mass index and other anthropometric variables in children with sickle cell anemia. Pak J Med Sci 2016;32:341-346

[9]. Phebus CK, Gloninger MF, Maciak BJ. Growth patterns by age and sex in children with sickle cell disease. J. Pediatr 1984;105(1):28-33.

[10]. Platt OS, Rosenstock W, Espeland MA. Influence of sickle hemoglobinopathies on growth and development. N. Engl. J. Med. 1984;311(1):7-12.

[11]. Zemel BS, Kawchak DA, Ohene-Frempong K, Schall JI, Stallings VA. Effects of delayed pubertal development, nutritional status and disease severity on longitudinal patterns of growth failure in children with sickle cell disease. Pediatr Res. 2007;61(5):607-613.

[12]. Beker L, Cheng TL. Principles of growth assessment. Pediatr Rev. 2006;27(5):196-198.

[13]. Nandanwar RA, Kamd NY. Sickle cell disease affects physical growth. Int J Pharm Bio Sci. 2013;4:784-789.

[14]. Kuczmarski RJ, Ogden CL, Grummer-Strawn LM, Flegel KM, Guo SS, Wei R, et al. CDC growth charts: United State. Adv Data. 2000;314:1-27 
[15]. Chawla A, Sprinz PG, Welch J, Heeney M, Usmani N, Pashankar F, et al. Weight status of children with sickle cell disease. Pediatrics. 2013;131(4): e11681173.

[16]. Mitchell MJ, Carpenter GJ, Crosby LE, Bishop CT, Hines J, Noll J. Growth status in children and adolescents with sickle cell disease. Pediatr Hematol Oncol. 2009;26(4):202-215.

[17]. Eke BC, Edelu BO, Ikefuna NA, Emodi JI, Ibe BC. Obesity in Preschool-Aged Children with Sickle Cell Anemia: Emerging Nutritional Challenge in a Resource Limited Setting. Pediatr Hematol Oncol. 2015;32(6):390-398

[18]. Akodu SO, Diaku-Akinwumi IN, Njokanma OF. Obesity-does it occur in Nigerian children with sickle cell anemia. Pediatr Hematol Oncol. 2012;29(4): 358364.

[19]. Ballas SK, Lieff S, Benjamin LJ, Dampier CD, Heeney MM, Hoppe C, et al. Definitions of the phenotypic manifestations of sickle cell disease Am J Hematol 2010;85:6-13

[20]. Oguanobi NI, Onwubere BJC, Ejim EC, Anisiuba BC, Ibegbulam OG, Ukekwe FI, et al. Cardiovascular system abnormalities in sickle cell anaemia: clinical findings in steady state adult Nigerian patients. J Clin Exp Cardilog 2016;7(3):423-427

[21]. Frankfort Horizontal Plane

[22]. https://www.merriam-webstar.com>frankfort (accessed on August 25th 2018)

[23]. BMI Formula-CDC

[24]. https://www.cdc.gov>childrens_bmi (accessed on August 25th 2018)

[25]. WHO-BMI for age

[26]. https://www.who.int/growthref/who2007_bmi_for_age (accessed on August 19th 2018)

[27]. Parab S, Bhalerao S. Choosing Statistical Test. Int J Ayuverda Res. 2010;1:187-191

[28]. Onukwuli VO, Ikefuna AN, Nwokocha AR, Emodi IJ, Eke CB. Relationship between zinc levels and anthropometric indices among school-aged female children with sickle cell anemia in Enugu, Nigeria. Niger J Clin Pract 2017;20:1461-1467

[29]. Barden EM, Zemel BS, Kawchak DA, Goran MI, Ohene-Frempong K, Stallings VA. Total and resting energy expenditure in children with sickle cell disease. J Pediatr 2000;136:73-79

[30]. Animasahun BA, Temiye EO, Ogunkunle OO, Izuora AN, Njokanma OF. The influence of socio-economic status on haemoglobin and anthropometry of SCA patients. Niger J Clin Pract 2011;14(4):422-427

[31]. Kazadi AL, Ngiyulu RM, Gini-Ehungu JL, MbuyiMuamba JM, Aloni MN. Factors Associated with Growth Retardation in Children Suffering from Sickle Cell Anemia: First Report from Central Africa. Anemia 2017;2017:1-6

[32]. Luban NL, Leikin SL, August GA. Growth and development in sickle cell anemia. preliminary report. Am J Pediatr Hematol Oncol 1982;4:61-5.
[33]. Singhal A, Gabay L, Serjeant GR. Testosterone deficiency and extreme retardation of puberty in homozygous sickle-cell disease. West Indian Med J 1995;44:20-23

[34]. Hall R, Gardner K, Rees DC, Chakravorty S. High body mass index in children with sickle cell disease: a retrospective single-centre audit. BMJ Paediatr Open 2018;2:e00302

[35]. Esezobor CI, Akintan P, Akinsulie A, Temiye E, Adeyemo T. Wasting and stunting are still prevalent in children with sickle cell anaemia in Lagos, Nigeria. Ital. J. Pediatr 2016; 42:45-52 